\title{
The Correlation Between Self-efficacy and Quality of Life in Elderly Who are Living with Hypertension
}

\author{
Maria Manungkalit, Linda Juwita \\ Faculty of Nursing, Widya Mandala Catholic University Surabaya, Jl. Raya Kalisari Selatan 1, Pakuwon City, Surabaya, \\ Indonesia \\ \{maria-manungkalit\}@ukwms.ac.id,lindajuwita@ukwms.ac.id
}

Keywords: Elderly, hypertension, quality of life, self-efficacy.

Abstract: The prevalence of hypertension was found to be high in the elderly globally. Self-efficacy plays an important role in the initiation and maintenance of health behavior, thus has an impact in determining quality of life (QOL). This study aimed to analyze the correlation between self-efficacy and QOL in elderly who are living with hypertension. This was a correlational study by using cross-sectional design approach. The population was all elderly with hypertension live in nursing home of St. Yosef Surabaya, amounting to 70 people. Sample size was 45 selected by purposive sampling technique. The independent variable was self-efficacy measured by General Perceived Self-Efficacy instrument. Dependent variable was QOL measured by WHOQOL-BREF instrument. Data analysis used Spearman Rank correlation test $(\alpha=.05)$. Result showed that majority was female $(57.78 \%)$, 75-90 years old $(55.56 \%)$, primary school graduated $(40.00 \%)$, and had a family history of hypertension $(82.22 \%)$. Most respondent had sufficient self-efficacy $(82.22 \%)$ with no low self-efficacy was found, and had sufficient QOL $(73.33 \%)$ with no high QOL was found. Self-efficacy was not correlated with QOL in elderly who are living with hypertension ( $\mathrm{p}=.456$ ). Various factors influenced the elderly's QOL, such as independency level, family support, socio-economic status, living standard, and culture.

\section{BACKGROUND}

Every individual will experience and face the aging process in the course of his life and this is a natural process that cannot be avoided. Being elderly is a process that takes place in life means someone has gone through the stages of life, namely neonatal, toddler, pre-school, school, adolescent, adult, and the elderly. This different stage of life begins both biologically and psychologically (Padila, 2013). Gradually, the elderly will experience changes in the ability of various organs, functions, and body systems that are natural / physiological. With many changes that occur in the elderly, elderly faces many problems, one of that is the increase of blood pressure (hypertension). Hypertension is an increase in systolic blood pressure of at least $140 \mathrm{mmHg}$ or diastolic pressure of at least $90 \mathrm{mmHg}$ (Price \& Wilson, 2006). Epidemiological investigations have shown that the occurrence of hypertension is closely related to morbidity and mortality of cardiovascular disease (Mutaqqin, 2009).

According to the data of Ministry of Health (MOH), Republic of Indonesia (RI) in 2014, there was an increase in number of elderly who had hypertension about $50 \%$. The incidence of hypertension in East Java in 2013 was $26.2 \%$. According to data of the Health Departement of Surabaya, number of hypertension cases in 2014 as much as $19.56 \%$ (Riskesdas, 2013).

The aging process is commonly associated with increased vascular rigidity and decreased vascular compliance. This process reflects the accumulation of smooth muscle cells and connective tissue in the walls of major blood vessels (Miyawaki, \& Lester, 2009). Endothelial cells and smooth muscle cells constitute most of vessel wall cellularity and the remainder of the wall is composed of extracellular matrix including collagen and elastin. Although aging has minimal effect on the muscular tunica media layer thickness, aging leads to profound progressive thickening of the tunica intima layer 
comprised of endothelial cells and an extracellular matrix. In addition, with aging, there is a thinning and separation of individual elastin lamellae, as well as an increase in the collagen matrix (O'Rourke, 2007; in Miyawaki, \& Lester, 2009). The age-related vascular rigidity and decreased arterial compliance leads to progressive increase in systolic BP, with $25 \%$ of patients over $75 \mathrm{yr}$ of age suffering from isolated systolic hypertension (Rowe, 1981; in Miyawaki, \& Lester, 2009).

Along with the increasing number of prevalence of hypertension incidence and complication of the disease, these will also impact on the QOL where the individual needs to make adjustments in order to remain able to perform its function optimally. Xavier, et al., (2003) concluded that elderly with poor QOL was equivalent to low health status, and good QOL was equivalent to good health status, more variety of activities, social life and good family relationships. Therefore health status is one of the good indicators of QOL in elderly. QOL reflects how one sees himself about his satisfaction of life (Philips, et al., 2009). The QOL of elderly can be influenced by level of independence as well. The success of self-reliance is not only related to health care, but also maximizing the psychological resources, such as self-efficacy, resilience, increased precautions, medical management during sick and illness, lifestyle changes by doing things that have a positive effect on health.

Self-efficacy theory was developed by Albert Bandura as a cognitive social theory in 1977 . He defined self-efficacy as a decisive belief in how one thinks, motivates himself and how one ultimately decides to conduct a behavior to achieve the desired goal. A study of Luszczynska's \& Dona (2005) about general self-efficacy suggested that self-efficacy can predict compliance in treatment regimens, health behaviors, physical activity, effective pain management, and disease management.

This study aimed to analyze the correlation between self-efficacy and QOL in elderly who are living with hypertension.

\section{METHODS}

This study utilized cross-sectional design. The population was all elderly with hypertension in St. Yosef elderly home of Surabaya which amounted to 70 people. Sample size was 45, selected by purposive sampling. Sample criteria were medical diagnosis was confirmed by a physician, duration of hypertension at least one month, willing to participate, and cooperative. Independent variable was is self-efficacy measured by instrument of General Perceived Self-efficacy developed by Bandura (1986) $(\alpha=.785, r=.447-.745)$. It consisted of 10 items examined by 1-4 Likert scale. The category of self-efficacy was low (score of 10-20), sufficient (score of 21-30), and high (score > 30). While the dependent variable was QOL measured by WHOQOL-BREF developed by World Health Ofrganization (WHO, 2004) ( $\alpha=.700, r=.419-.798)$. It consisted of 4 items assessing 4 domains of QOL, such as, physical, psychological, social, and environmental. Raw score in each domain was transformed into 0-100 range. The category of QOL was low (score of 0-40), sufficient (score of 41-69), and high (score of 70-100). All data was in ordinal scale, so that Spearman Rank correlation test was used for data analysis $(\alpha<.05)$. Ethical aspect was assured by principal of anonimity, beneficence, nonmaleficence, fidelity, and confidentialty implemented in this study. Informed consent was signed by all respondents.

\section{RESULTS}

There were 45 elderly with hypertension who are living in an elderly home of St. Yosef of Surabaya participated in this study. Age range was $66-97$ years old. Most respondents were female (57.78\%), $75-90$ years old $(55.56 \%)$, primary school graduated (40\%), and had a family history of hypertension (82.22\%). Table 1 explains demography characteristic of study respondents.

Table 1. Demography characteristic

\begin{tabular}{|l|c|c|}
\hline \multicolumn{1}{|c|}{ Characteristic } & n & \% \\
\hline 1. Sex & 19 & 42.22 \\
a. Male & 26 & 57.78 \\
b. Female & & \\
\hline 2. Age (years old) & 18 & 40.00 \\
a. 60-74 & 25 & 55.56 \\
b. 75-90 & 2 & 4.44 \\
c. >90 & & \\
\hline 3. Family history with & & \\
hypertension & 37 & 82.22 \\
a. Yes & 8 & 17.78 \\
b. No & & \\
\hline 4. Educational background & 18 & 40.00 \\
a. Primary school & 14 & 31.11 \\
b. Secondary school & 7 & 15.56 \\
c. High school & 4 & 8.89 \\
d. Diploma & 2 & 4.44 \\
e. Bachelor degree & & \\
\hline
\end{tabular}


Most respondents had sufficient self-efficacy $(82.22 \%)$ and sufficient QOL $(73.33 \%)$. Selfefficacy was uncorrelated with QOL in elderly with hypertension $(p=.456)$. Table 2 explains the result of descriptive statistical analysis.

Table 2: Table of frequency and descriptive statistic

\begin{tabular}{|c|c|c|c|c|}
\hline \multirow{2}{*}{ Category } & \multicolumn{2}{|c|}{ Self-efficacy } & \multicolumn{2}{c|}{ QOL } \\
\cline { 2 - 5 } & $\mathbf{n}$ & $\boldsymbol{\%}$ & $\mathbf{n}$ & $\boldsymbol{\%}$ \\
\hline Low & 0 & 0 & 12 & 26.67 \\
\hline Sufficient & 37 & 82.22 & 33 & 73.33 \\
\hline High & 8 & 17.78 & 0 & 0 \\
\hline Mean & \multicolumn{2}{|c|}{28.27} & \multicolumn{2}{c|}{46.09} \\
\hline Std. Deviation & \multicolumn{2}{|c|}{3.39} & \multicolumn{2}{c}{9.30} \\
\hline
\end{tabular}

Table 3: Result Of Spearman's Correlation Test Correlations

\begin{tabular}{|c|c|c|c|c|}
\hline & & & ED & QOL \\
\hline \multirow[t]{6}{*}{$\begin{array}{l}\text { Spearman } \\
\text { 's rho }\end{array}$} & \multirow[t]{3}{*}{ ED } & $\begin{array}{l}\text { Correlation } \\
\text { Coefficient }\end{array}$ & 1.000 & -.114 \\
\hline & & Sig. (2-tailed) & . & .456 \\
\hline & & $\mathrm{N}$ & 45 & 45 \\
\hline & \multirow[t]{3}{*}{ QOL } & $\begin{array}{l}\text { Correlation } \\
\text { Coefficient }\end{array}$ & -.114 & 1.000 \\
\hline & & Sig. (2-tailed) & .456 & . \\
\hline & & $\mathrm{N}$ & 45 & 45 \\
\hline
\end{tabular}

\section{DISCUSSION}

Self-efficacy in elderly who are living with hypertension defined as self-confidence and competency for doing some tasks, such as diet management, physical exercise, drugs administration, stress management, socialize with others, occupational therapy, etc., to achieve the goal of normal blood pressure. Most respondents had sufficient self-efficacy. This potentially influenced by cognitive function, affective, and selection process in elderly's state of mind (Bandura, 1997 in Guffron \& Risnawati, 2014).

Cognitive function is a conscious mental activity, such as thinking, remembering, learning and using language. Cognitive function is also the ability of paying attention, memory, consideration, problem solving, and the ability of executive competency such as planning, assessing, monitoring and evaluating (Strub, et al., 2000). In elderly people, we found decreased cognitive function generally. Memory is one of the earliest cognitive function which decline. Long-term memory is less likely to change, while short-term memory is instantly changes in 0-10 minutes. For declining intellectual functions, the fluid intelligent such as list recall, geometric memory, word finding speed, problem solving, responsiveness, and attention quickly diverted (Kusumoputro, 2004). The ability to understand or grasp the understanding of the elderly has decreased. This is influenced by the decreased in concentration and hearing function. In the elderly, the problems faced more and more by time. Many things can easily be solved in ancient times, but are now hampered by the decline in cognitive function. Other obstacles are derived from memory loss, comprehension, and others that result in more problem-solving difficulties (Azizah, 2011).

In performing individual tasks, we need to set the goals and objectives of behavior so that individuals can formulate appropriate actions to achieve those goals. The setting of personal goals is influenced by the individual's assessment of his cognitive abilities. Cognitive function allows individuals to predict the daily events that will result in the future. The assumption that arises on this cognitive aspect is the more effective the individual's ability in analyzing and in practicing to express his personal ideas. It will support the individual to act appropriately to achieve the expected goal. Individuals will foresee events and develop ways to control events that affect their lives. This expertise requires an effective cognitive process of various kinds of information (Bandura, 1997 in Guffron \& Risnawati, 2014).

Affection occurs naturally within the individual and plays a role in determining the intensity of the emotional experience. Affection is directed by controlling anxiety and depressive feelings that hinder the right mind set to achieve goals. The process of affection is related to the ability to cope with emotions that arise in self to achieve the expected goals. The individual's belief in his ability to influence the level of stress and depression experienced when faced with difficult or threatening tasks. Individuals who believe they are capable of controlling a threat will not arouse an intrusive mind set. Individuals who do not believe in their abilities will experience the anxiety of not being able to manage the threat (Bandura, 1997 in Guffron \& Riisnawati, 2014).

The selection process relates to the individual's ability to select appropriate behavior and environment, so as to achieve the expected objectives. Individual inability to perform behavioral selection makes individuals unconfident, confused, and easily give up when faced with difficult problems or situations. Self-efficacy can shape the lives of individuals through the selection of activity and environment types. Individuals will be able to 
carry out challenging activities and choose situations that are believed to be capable of handling. Individuals will maintain competence, interests, and social relationships over the prescribed choice. It can be concluded that the process of self-efficacy includes cognitive, affection, and selection processes (Bandura, 1997 in Guffron \& Risnawati, 2014).

Study result showed that there was no correlation between self-efficacy and quality of life (QOL) in elderly who are living with hypertension. QOL has been used as an indicator of how well a society meets the needs of its elderly. There are various potential variables mediate the relationship between self-efficacy and QOL or possibly affecting QOL stronger than self-efficacy alone in this study context. Generally, QOL is influenced by living standard. Reasonable standard of living has changed with time and cultural settings. In a society with inequalities in living standard, there is elevated stress level, especially in the lowest socio-economic status, leading to poorer health and even lower life satisfaction (Marmot \& Richard, 2006). Low socioeconomic status possibly affects QOL because financial insecurity or problems has led to high stress level among elderly in general, especially related to retirement and family neglect.

Although QOL scores tends to decreased with increasing age, a support of physical functions optimization in older adults can be important for increasing QOL and functional independence (Bozkurt \& Yilmaz, 2016). In elderly with hypertension, some vascular risk factors are associated with functional impairment due to clinical and subclinical vascular disease (Canavan, et al, 014). Age-related physiological changes also bring a reduction in functional capabilities resulted in problems with self-care, activities of daily life, and psychosocial problems. It has been identified that intense exercise was not an obligatory condition for optimal QOL in elderly people. Active part in moderate intensity daily activities associated with higher QOL (Pavlova, et al., 2015).

Other factor that possibly affects QOL in elderly who are living with hypertension is social support, especially from family subgroup. Elderly living with their spouse and children had better social support family subgroup scores compared to ones living alone. A positive correlation was found between social support and QOL (Unsar, et al, 2016). A study in Korea towards 1,056 elderly showed that the elderly who give and receive family support had higher QOL than the one who only receive support. Elderly and the younger generation put more value on two-way intergenerational relation based on mutual care and assistance (Kim \& Cheong-Seok, 2003). Family and friend support are different across ethnic because culture also influence the support pattern in our society (Poulin et al, 2012).

Cultural factor could also be a potential factor influencing QOL Social and cultural norms, informed by religious principles that prescribe familial elder care, impact how QOL is described by elderly. It is also possible that religious faith or traditions might provide a different account of how individual's own religious faith impacts expectations of care and QoL in old age (Shreshta \& Zarit, 2012). A study in Singapore towards elderly showed that QOL was more likely to be determined by sociocultural context rather than along racial lines (Wong, 2003).

\section{CONCLUSIONS}

There was no correlation between self-efficacy and QOL in elderly who are living with hypertension. Self-efficacy was potentially influenced by cognitive function, affective, and selection process in elderly's state of mind. Independency level, family support, socio-economic status, living standard, and culture were potentilly influenced QOL in elderly who are living with hypertension stronger than self-efficacy.

\section{ACKNOWLEDGEMENTS}

This study and publication were funded by Faculty of Nursing, Widya Mandala Catholic University Surabaya (WMCUS).

\section{REFERENCES}

Azizah. (2011). Keperawatan Lanjut Usia. Yogyakarta: Graha Ilmu

Bozkurt, Ü., Yilmaz, M. 2016. The determination of functional independence and quality of life of older adults in a nursing home. International Journal of Caring Sciences, 9(1): 198-210.

Canavan, M., Glynn, L.G, Smith, A., Mulkerrin, E.C., Murphy, A.W., Mulqueen, J., McGrath, E., O'Donnell, M.J. 2014. Vascular risk factors, cardiovascular disease and functional impairment in community-dwelling adults. Gerontology, 60(3): 212-221.

Corwin, E.J. 2009, Buku Saku Patofisiologi, edisi 3. Jakarta: EGC. 
Kim, I.K., Kim, C.S. 2003. Patterns of family support and the quality of life of the elderly. Social Indicators Research, 62(1): 437-454.

Kusumoputro, S. 2004. Mengenal Awal Pikun Alzheimer. Jakarta: UI-press.

Luszczynska, A., Dona, B.G. 2005. General selfefficacy in various domains of human functioning: evidence from five countries. International Journal of Psychology, 40(2): 80-89.

Marmot, M., Richard, G.W. 2006, Sosial Determinants of Health. $2^{\text {nd }}$. Ed., USA: Oxford University Press.

Miyawaki, N.B., Lester, P.E. (2009). Vascular disease in the elderly. Geriatric Nephrology Curriculum: $1 / 5$

Muttaqin, A. (2009). Asuhan Keperawatan Klien dengan Gangguan Sistem Kardiovaskular dan Hematologi. Jakarta: Salemba Medika.

Padila. (2013). Asuhan Keperawatan Penyakit Dalam. Yogyakarta: Nuha Medika.

Pavlova, I., Bogdan, V., Borek, Z., Borek, I. 2015. Life quality and physical activity of Ukrainian residents. Journal of Physical Education and Sport, 124: 809-814.

Price, S.A., Wilson, L.M. (2006). Patofisiologi: Konsep Klinis Proses-proses Penyakit, Edisi 6, Volume 1. Jakarta: EGC.

Poulin, J., Deng, R., Ingersoll, T.S., Witt, H., Swain, M. 2012. Perceived family and friend support and the psychological well-being of American and Chinese elderly persons. J Cross Cult Gerontol, 27(4): 305-17.

Riskesdas. (2013). Badan Penelitian dan Pengembangan Kesehatan Kementrian Kesehatan Republik Indonesia. Retrieved from: http://www.depkes.go.id/resources/download/ge neral/Hasil\%20Riskesdas\%202013.pdf.

Shrestha, S., Zarit, S.H. 2012. Cultural and contextual analysis of quality of life among older Nepali women. J Cross Cult Gerontol, 27(2): 163-182.

Strub, R.L., Black, F.W. (2000). The Mental Status Examination in N,eurology 4th Ed., Philadelphia: F. A. Davis.

Unsar, S., Erol, O., Sut, N. 2016. Social support and quality of life among older adult. International Journal of Caring Sciences, 9 (1): 249-257.

Wong, G.K.M. 2003. Quality of life of the elderly in Singapore's multi-racial society. International Journal of Social Economics, 30(3): 302-319.

WHO. (2004). Instrument BREF. Retrieved from: www.who.int 